\title{
OCEANIC ANGLERFISHES
}


This page intentionally left blank 


\section{OCEANIC ANGLERFISHES}

EXTRAORDINARY DIVERSITY IN THE DEEP SEA

THEODORE W. PIETSCH

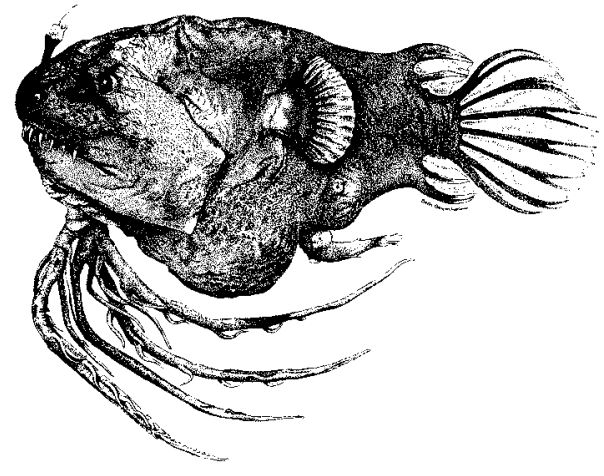

甲

UNIVERSITY OF CALIFORNIA PRESS Berkeley Los Angeles London 
University of California Press, one of the most distinguished university presses in the United States, enriches lives around the world by advancing scholarship in the humanities, social sciences, and natural sciences. Its activities are supported by the UC Press Foundation and by philanthropic contributions from individuals and institutions. For more information, visit www.ucpress.edu.

University of California Press

Berkeley and Los Angeles, California

University of California Press, Ltd.

London, England

(C) 2009 by the Regents of the University of California

Published with the assistance of the University of Washington

The material in this volume is based on work supported by the U.S. National Science Foundation under Grants GB-40700, DEB 76-82279, DEB 78-26540, DEB 03-14637, T.W. Pietsch, principal investigator. Any opinions, findings, conclusions, or recommendations expressed in this work are those of the author and do not necessarily reflect the views of the Foundation.
Library of Congress Cataloging-in-Publication Data

Pietsch, Theodore W.

Oceanic anglerfishes : extraordinary diversity in the deep sea / Theodore W. Pietsch.

p. $\mathrm{cm}$.

Includes bibliographical references and index.

ISBN 978-0-520-25542-5 (case : alk. paper) 1. Anglerfishes. 2. Anglerfishes-Classification. I. Title.

QL637.9.L6P54 2009

$597^{\prime} .62-\mathrm{dc} 22$

2008048604

Manufactured in Singapore

$\begin{array}{llllllll}16 & 15 & 14 & 13 & 12 & 11 & 10 & 09\end{array}$

$\begin{array}{llllllllll}10 & 9 & 8 & 7 & 6 & 5 & 4 & 3 & 2 & 1\end{array}$

The paper used in this publication meets the minimum requirements of ANSI/NISO Z39.48-1992 (R 1997) (Permanence of Paper). $\infty$

Cover illustration: Artwork by Ray Troll, 2007

Title-page illustration: Linophryne brevibarbata, 100-mm SL female, with an 18.5-mm SL parasitic male, BMNH 1995.1.18.4, a North Atlantic species represented in collections around the world by only six specimens. Drawing by Elisabeth Beyerholm; after Bertelsen (1980a). 
Dedicated to the memory of the late Erik Bertelsen 
This page intentionally left blank 